\title{
Application of Problem Based Learning Models to Improve Magnetic Materials Learning Results
}

\section{Anisa Dwi Inayati Shahab}

SDN 1 Jambukulon

anisa.ali.shahab@gmail.com

\section{Article History}

accepted 14/11/2020

\begin{abstract}
The purpose of this study was to improve the learning outcomes of Magnetics subject in elementary schools in grade VI by applying the Problem Based Learning (PBL) learning model. The research conducted was a Classroom Action Research (PTK) in three cycles, with each cycle consisting of 1 meeting. The stages of each cycle are planning, implementing, observing and reflecting. Each meeting is held an evaluation to determine the progress of learning outcomes. In cycle 1, students who completed after the evaluation were $51.61 \%$. In cycle 2, students who completed after evaluation were $74.20 \%$. In cycle 3, students who completed after the evaluation were $90.32 \%$. These results indicate that the Problem Based Learning (PBL) learning model can improve student learning outcomes, especially science muple class VI magnetic materials at SDN 1 Jambukulon.
\end{abstract}

Keywords: problem based learning (pbl), learning outcomes, science

\section{Abstrak}

Tujuan dari penelitian ini adalah untuk meningkatkan hasil belajar IPA materi Magnet di sekolah dasar kelas VI dengan menerapkan model pembelajaran Problem Based Learning (PBL). Penelitian yang dilakukan adalah Penelitian Tindakan Kelas (PTK) sebanyak tiga siklus, dengan setiap siklusnya terdiri dari 1 pertemuan. Tahapan setiap siklusnya adalah perencanaan, pelaksanaan, observasi dan refleksi. Setiap pertemuan diadakan evaluasi untuk mengetahui perkembangan hasil belajarnya. Pada siklus 1 , peserta didik yang tuntas setelah evaluasi sebanyak $51,61 \%$. Pada siklus 2 , peserta didik yang tuntas setelah evaluasi sebanyak 74,20 $\%$. Pada siklus 3, peserta didik yang tuntas setelah evaluasi sebanyak $90,32 \%$. Hasil ini menunjukkan bahwa model pembelajaran Problem Based Learning (PBL) dapat meningkatkan hasil belajar peserta didik khususnya mupel IPA materi magnet Kelas VI di SDN 1 Jambukulon.

Kata kunci: Problem Based Learning (PBL), Hasil belajar, IPA

Social, Humanities, and Education Studies (SHEs): Conference Series https://jurnal.uns.ac.id/shes

p-ISSN 2620-9284

e-ISSN 2620-9292 


\section{PENDAHULUAN}

Pendidikan adalah usaha sadar dan terencana untuk mewujudkan suasana belajar dan proses pembelajaran agar peserta didik secara aktif mengembangkan potensi dirinya untuk memiliki kekuatan spiritual keagamaan, pengendalian diri, kepribadian, kecerdasan, akhlak mulia, keterampilan yang diperlukan dirinya dan masyarakat (Departemen Pendidikan dan perpustakaan, 2003:62). Pendidikan bukan sekedar memberikan pengetahuan, nilai-nilai atau melatih ketrampilan. Pendidikan berfungsi mengembangkan kemampuan potensial dan aktual telah dimiliki oleh peserta didik, sebab peserta didik bukanlah gelas kosong yang harus diisi dari luar.

Dewasa ini, proses pembelajaran yang berpusat pada guru (teachercenter) masih banyak diterapkan oleh para guru di kelas. Pembelajaran yang demikian lebih mementingkan hasil daripada proses pembelajaran itu sendiri, sehingga pembelajaran terkesan monoton. Yang menjadi permasalahan adalah ketika dalam menyampaikan materi di kelas, guru selalu menerapkan metode pembelajaran yang seperti itu secara terus menerus dan menjadi kebiasaan sehingga peserta didik menjadi kurang aktif dan kesulitan dalam memahami materi yang disampaikan. Oleh karena itu proses pembelajaran yang masih berpusat pada guru sudah seharusnya di ubah menjadi proses pembelajaran yang berpusat pada peserta didik. Persoalan hasil belajar di kelas VI SDN 1 Jambukulon mengalami masalah yang serius. Hal itu berdasarkan ulangan harian pada peserta didik diperoleh nilai rata-rata ulangan harian siswa yang hanya 71, padahal KKM yang ditentukan sekolah adalah 75 untuk setiap muatan pembelajaran. Dari 31 siswa hanya ada $40 \%$ anak yang lulus KKM, sedangkan $60 \%$ lainnya tidak mencapai KKM.

Didalam pelaksanaan proses pembelajaran berdasarkan Kurikulum 2013 guru dituntut untuk menguasai berbagai model pembelajaran dengan pendekatan saintifik. Salah satu model pembelajaran dengan pendekatan saintifik adalah model Problem Based Learning. Problem Based Learning merupakan model pembelajaran yang memberikan kesempatan penuh bagi siswa untuk menjadi pembelajar aktif yang selalu mencari dan menemukan pengetahuan yang dimilikinya. Model pembelajaran Problem Based Learning menjadikan peserta didik sebagai pusat pembelajaran dan menekankan belajar secara kooperatif. Sementara guru disini berperan sebagai fasilitator yang memfasilitasi siswa dalam pembelajaran untuk secara aktif menyelesaikan masalah. Ibrahim dan Nur (dalam Rusman, 2012: 243) mengemukakan langkah-langkah Problem Based Learning adalah sebagai berikut : "(1) Orientasi peserta didik pada masalah, (2) Mengorganisasi peserta didik untuk belajar, (3) Membimbing pengalaman individual/kelompok, (4) Mengembangkan dan menyajikan hasil karya, dan (5) menganalisis dan mengevaluasi proses pemecahan masalah". Dengan cara belajar seperti itu, maka akan memberikan pengalaman belajar yang bermakna bagi peserta didik. Melalui proses pemecahan masalah peserta didik akan mengetahui situasi dimana konsep materi diterapkan. Berdasarkan paparan di atas pemecahan masalah belajar yang dilakukan dengan model pembelajaran Problem Based Learning layak dilakukan penelitian tindakan kelas pada peserta didik kelas VI SDN 1 Jambukulon.

\section{METODE}

Penelitian ini adalah penelitian tindakan kelas (Classroom Action Research) dengan menerapkan model pembelajaran Problem Based Learning (PBL). Penelitian tindakan kelas ini terdiri dari empat tahap dasar yaitu perencanaan (planning), pelaksanaan (acting), pengamatan (observing) dan refleksi (reflecting). Analisis penelitian ini adalah analisis deskriptif kuantitatif kualitatif dimana dalam penelitian ini selain menyajikan hasil berupa data maupun angka peneliti juga menentukan bagaimana cara pengolahan hasil penelitian yakni dengan membuat analisisnya dengan menerapkan model pembelajaran Problem Based Learning (PBL). Penelitian 
ini dilaksanakan pada peserta didik kelas VI SD Negeri 1 Jambukulon Tahun Pelajaran 2020/2021 selama 3 siklus secara daring menggunakan aplikasi whatsapp dan zoom claud meeting dengan satu pertemuan disetiap siklusnya. Siklus I dilaksanakan pada tanggal 9 November 2020. Siklus II dilaksanakan pada tanggal 16 November 2020. Siklus III dilaksanakan pada tanggal 20 November 2020. Teknik pengumpulan datayang dilakukan dengan observasi dan tes. Untuk hasil belajar menggunakan tes melalui google form.

\section{HASIL DAN PEMBAHASAN}

Setelah menerapkan model pembelajaran Problem Based Learning, pada hasil belajar peserta didik kelas VI di SDN 1 Jambukulon, dapat diketahui hasil belajar peserta didik yang dapat digambarkan pada tabel berikut ini :

\section{Tabel 1. Hasil Belajar Peserta DIdik}

\begin{tabular}{lccc}
\hline \multicolumn{1}{c}{ Hasil Belajar } & \multicolumn{3}{c}{ Siklus } \\
\hline Nilai tertinggi & 90 & KE2 & KE3 \\
Nilai Terendah & 50 & 100 & 100 \\
Rata-rata kelas & 72,23 & 80,00 & 87,09 \\
Jumlah tuntas & 16 & 23 & 28 \\
Jumlah tidak tuntas & 15 & 8 & 3 \\
Prosentase tuntas & $51,61 \%$ & $72,20 \%$ & $9,68 \%$ \\
Prosentase tidak tuntas & $48,39 \%$ & $25,80 \%$ & $90,32 \%$
\end{tabular}

Berdasarkan tabel 1 tersebut, dapat terlihat bahwa terdapat peningkatan ratarata nilai hasil belajar mulai dari siklus I, siklus II dan siklus III. Pada siklus I nilai ratarata siswa hanya mencapa73,22 hal ini masih jauh dibawah kriteria ketuntasan minimal (KKM) yang telah ditentukan di SDN 1 Jambukulon yaitu 75 . Kemudian, dilaksanakan penelitian tindakan kelas dengan penerapan model pembelajaran Problem Based Learning pada siklus II yang menunjukkan peningkatan hasil belajar siswa menjadi 80 , hal ini sebenarnya sudah mencapai indikator capaian penelitian yaitu $\leq 75$ namun masih ada beberapa peserta didik yang belum tuntas sehingga peneliti bersama dengan guru observer merasa bahwa hal tersebut masih dapat ditingkatkan, kemudian dilaksanakan siklus III, dari siklus III diketahui bahwa rata-rata hasil belajar siswa meningkat kembali mencapai 87,09.

Adanya peningkatan rata-rata hasil belajar siswa juga didukung dengan adanya peningkatan jumlah siswa yang mengalami ketuntasan hasil belajar. Dari 31 peserta didik, pada saat siklus I yang mengalami ketuntasan hasil belajar hanya berjumlah 16 peserta didik dengan presentase $51,61 \%$, kemudian pada siklus II jumlah peserta didik yang mengalami ketuntasan hasil belajar meningkat menjadi 23 peserta didik dengan presentase $74,20 \%$, dan pada siklus III jumlah peserta didik yang mengalami ketuntasan belajar meningkat kembali menjadi 28 siswa dengan presentase $90,23 \%$.

Dari penelitian yang dilakukan peneliti bersama guru observer dengan penerapan model pembelajaran Problem Based Learning (PBL) tersebut, terlihat bahwa pembelajaran dengan menggunakan model Problem Based Learning (PBL) yang telah diterapkan mempunyai beberapa kelebihan dan kelemahan seperti yang diutarakan oleh Sanjaya (2006:220). Kelebihan tersebut diantaranya, peserta didik dapat memahami isi pembelajaran dengan baik karena mereka selalu terpacu untuk membaca materi dan PBL dapat membantu peserta didik mengembangkan 
pengetahuannya serta dapat digunakan sebagai evaluasi diri terhadap hasil maupun proses belajar, terbukti dengan adanya peningkatan hasil belajar selama tindakan. Adapun kelemahannya adalah konsumsi waktu, sebab model pembelajaran ini membutuhkan waktu yang tidak sedikit.

Penelitian Tindakan Kelas dengan model pembelajaran Problem Based Learning (PBL) ini sesuai dengan teori belajar konstruktivisme, PBL mendorong peserta didik mengkonstruksi pengetahuannya sendiri melalui permasalahan nyata yang membutuhkan suatu pemecahan masalah. Dari beberapa teori konstruktivisme, yang paling sesuai dari proses pembelajaran yang telah dilaksanakan adalah teori konstruktivisme menurut Vygotski, sebab ketika peserta didik terlibat dalam kegiatan diskusi yang dilaksanakan pada tiap siklusnya, mereka akan saling bertukar pendapat dan informasi, sehingga konsep dari materi tersebut dapat ditemukan peserta didik. Konstruktivisme Vygotski memandang bahwa pengetahuan dikonstruksi secara kolaboratif antar individual dan keadaan tersebut dapat disesuaikan oleh setiap individu. Ini berarti bahwa konstruktivisme Vygotski lebih menekankan pada penerapan teknik saling tukar pendapat dan gagasan antar individu dalam kegiatan kelompok sehingga peserta didik dapat menemukan konsep secara mandiri, seperti halnya yang dilakukan peserta didik kelas VI pada kegiatan diskusi.

Berdasarkan peningkatan hasil belajar tersebut membuktikan proses pembelajaran model Problem Based Learning memberikan pengalaman belajar yang bermakna bagi peserta didik. Melalui proses pemecahan masalah peserta didik akan mengetahui situasi dimana konsep materi diterapkan., serta meningkatkan pemahaman konsep materi ajar yang nantinya akan berimbas pada hasil belajar yang lebih optimal. Hal ini seperti yang dikatakan Moffit (dalam Rusman, 2012: 241), bahwa Problem Based Learning merupakan suatu pendekatan pembelajaran yang menggunakan masalah dunia nyata sebagai suatu konteks bagi peserta didik untuk belajar tentang berpikir kritis dan ketrampilan pemecahan masalah serta untuk memperoleh pengetahuan dan konsep yang esensi dari materi pelajaran.

Dari hasil tindakan, pengamatan dan pembahasan dapat ditarik kesimpulan bahwa penerapan model pembelajaran Problem Based Learning (PBL) dapat meningkatkan hasil belajar peserta didik pada mupel IPA materi Magnet Kelas VI SDN 1 Jambukulon tahun ajaran 2020/2021.

\section{SIMPULAN}

Merujuk pada hasil penelitian yang telah dilakukan, dapat disimpulkan bahwa penerapan model Problem Based Learning pada materi Magnet dapat meningkatkan hasil belajar IPA peserta didik kelas VI SDN 1 Jambukulon Tahun Ajaran 2020/2021 yang dibuktikan dengan peningkatan hasil belajar siswa dilihat dari peningkatan nilai rata-rata dan peningkatan persentase ketuntasan klasikal hasil belajar. Nilai rata- rata hasil belajar peserta didik pada penelitian siklus I sebesar 72,23 meningkat menjadi 80 pada siklus II kemudian meningkat lagi menjadi 87,09. Presentase ketuntasan klasikal hasil belajar pada siklus I sebesar $51,61 \%$ meningkat $72,20 \%$ pada siklus II, dan presentase ketuntasan siklus III menjadi $90,32 \%$ dari keseluruhan peserta didik kelas VI yaitu 31 peserta didik.

Berdasarkan paparan hasil penelitian ini, maka peneliti mengajukan saransaran sebagai berikut:

1. Para guru disarankan menggunakan model Problem Based Learning sebagai salah satu alternatif dalam pembelajaran IPA karena terbukti pada pembelajaran materi Magnet dapat meningkatkan hasil belajar peserta didik.

2. Guru diharapkan mampu menerapkan variasi model pembelajaran dalam proses 
mengajar di kelas, sehingga peserta didik tidak mengalami kejenuhan dengan satu model saja secara terus-menerus.

3. Peserta didik sebaiknya dapat berperan aktif dalam proses pembelajaran di dalam kelas, mampu mengemukakan ide atau pendapatnya serta dapat bekerja sama dengan teman satu kelompoknya untuk melaksanakan kegiatan diskusi dan melakukan penyelidikan tugas kelompok dalam memecahkan suatu permasalahan sehingga secara bersama-sama dapat menentukan alternatif pemecahan masalah.

4. Peserta didik hendaknya lebih bersungguh-sungguh dalam mengikuti proses pembelajaran di kelas dan fokus pada penjelasan guru serta aktif pada kegiatan diskusi

\section{DAFTAR PUSTAKA}

Aqib, Zainal. 2014. Penelitian Tindakan Kelas. Bandung: Yrama Widya

Arikunto, Suharsimi, dkk. 2010. Penelitian Tindakan Kelas. Jakarta: PT Bumi Aksara

Sanjaya, Wina. 2007. Strategi Pembelajaran : Berorientasi Standar Proses Pendidikan. Jakarta : Kencana Prenada Media

Rusman. 2014. Model-Model Pembelajaran: Mengembangkan Profesionalisme Guru. Jakarta: PT Rajagrafindo Persada

Rusmono. 2012. Strategi Pembelajaran dengan Problem Based Learning Itu Perlu. Jakarta: Ghalia Indonesia 